\title{
How to Measure Benefits of Non-standard Healthcare Systems
}

\section{Renata Kunstova, Martin Potancok}

\author{
University of Economics \\ W. Churchill Sq. 4, 13067 Prague 3, Czech Republic \\ e-mail:kunstova@vse.cz,xpotm03@vse.cz
}

cross $^{\text {ref }}$ http://dx.doi.org/10.5755/j01.ee.24.2.2515

\begin{abstract}
One of the ways, how to improve the quality of patient care is hidden in modern information technologies. They can increase the timeliness and accuracy of patient care. Their impact should be assessed from several perspectives: the quality and availability of medical information, quality of diagnostic decisions and health care services. On the one hand, information technologies have a potential to improve health care quality, safety and patient satisfaction, but, on the other hand, require financial investment. Every investment project needs to specify its goals and measurable benefits. Indirect costs which are difficult to measure might be challenging in the evaluation of financial investment.

Healthcare information technologies can improve the quality of health care, support treatment and consequently contribute to patients' health. Examples of such systems are patient monitoring technologies. The benefits of these technologies are for the patient, health care facility and personnel. They decrease the number of personnel and errors. These devices can provide information directly to a healthcare information system.

Considering all of the above, this paper aims to present a procedure of how to measure the benefits of non-standard healthcare systems. Based on statistically proven facts, we identify problems that can eliminate financial investment in non-standard healthcare systems. These investments are balanced by the benefits to both the medical staff and patients.
\end{abstract}

Keywords: Health service, monitoring information system, hospital bed management information system, measuring of benefits.

\section{Introduction}

Decision making on investments is always a very difficult and responsible process. Investments in information technologies (IT) especially require the quantification of benefits because they are often confronted with a number of barriers. Our research, described in this paper, builds on the results of the wide national survey (Pour et al., 2011), which was realized within our grant project "Advanced Principles and Models for Enterprise ICT Management". Our team deals with new principles and models for enterprise IT management (Feuerlicht, 2010; Kunstova, 2010, 2011a,b, 2012; Vorisek et al., 2010, 2011), which also includes measuring and quantifying the benefits of investment in information technologies (Maryska, 2010, $2011 \mathrm{a}, \mathrm{b}, \mathrm{c})$. The survey covered several research issues and 600 companies operating on the Czech market participated. Twenty four companies from the health sector were surveyed. The survey showed that a lack of finance and other savings measures is the most frequent barrier to investment into information technologies. This overall result was confirmed by $79 \%$ of respondents from the health sector, which answered identically. We compared this result with another research (Kaye, 2010; NCR, 2009; de Lusignan, 2008). For instance, the research from the Healthcare Informatics Research Series (NCR, 2009) also found costs consistently cited as the number one barrier to IT investment among all types of healthcare delivery organizations. Spending slow downs, pauses or freezes of IT projects have been imposed in many hospitals. The recent economic crisis has increased a pressure to demonstrate the benefits of any investment.
From the economic point of view, costs play the main role because almost all management decisions are based on a comparison of costs with profits (Atkinson et al., 2000). However, in the health sector, it is also necessary to assess the quality of health care not only financial costs (Ilminen, 2003). The main goal of investment in health care information systems is moreover very closely connected with the goal of improving the quality of health care. This quality is hardly measurable. According to the study of Piligrimiene and Buciuniene (2008), it should be evaluated in several dimensions from patient, physicians to managers' point of views. One of the dimensions is the system's efficiency - optimal use of available resources (material, personnel, information, financial) to yield maximum results. Ilminen mentioned (Ilminen, 2003) that we first need to determine what to measure and how to measure it, then the next problem is to get accurate, complete data quickly enough to derive useful measurements. Measurements of health care safety and quality may be useful for screening and ruling out a problem for diagnosing a problem and for monitoring progress (Elzinga, 2003). According to Scobie (Scobie, 2006), quantitative and qualitative measures are both useful in different ways.

The publication "Health at a Glance" (OECD, 2011) presents comparable data on key indicators of health and the health system across OEDC countries. These data are the results of quantitative measurement. For instance, the number of hospital beds provides a measure of the resources available for delivering services to patients in hospitals. However, the type of the beds, in terms of quality of patient care, is not examined further. We decided 
to find indicators that demonstrate improvement in the quality of patient care and benefits to hospitals.

The research problem is to show how benefits from investments which improve health care could be evaluated.

The aim of this paper is to demonstrate an evidence of the benefits following from an extension of medical information systems by a patient monitoring system.

The object of the paper is using of special hospital and nursing-care beds with the monitoring system which improves the level of patient care.

The research methods used were as follows: first, we analysed selected data from five surveys to identify key indicators for measuring benefits of beds with the monitoring system. Secondly, we analysed the nursing processes in two hospitals and realised measurement of key indicators before and after implementation of the monitoring system. Finally, we described the value added model of non-standard healthcare systems from the viewpoint of three groups of medical facilities.

The structure of the following text is as follows. First we briefly describe the additional monitoring software and its purpose in the improvement of health care and then we discuss the partial results.

\section{Additional monitoring software}

Examples of investments leading to the improvement of the level of patient care are hospital and nursing-care beds that allow the contactless vital signals monitoring and the presence detection of the patient in the bed.

These modern beds are able to provide more than just a place for the patient. The combination of beds and information systems brings new possibilities, such as monitoring and alerting. LINET is the only company in the world which equips beds with the contactless vital signals monitoring and connects beds to LINis and Vitalmonitor systems. System LINis is able to monitor beds from the LINET company in real time. Its goal is to monitor constantly individual parts of beds, collect and analyse all data. The functionality of the entire bed is also verified. The current version is able to work with the following parameters: bed position, position of side rails, bed height, backrest position, bed load (and thus the presence of the patient), battery status, defects in electronic components and others. Various alerts and warnings are displayed in emergency. System Vitalmonitor is focused on a real time monitoring of patients' vital functions. The whole technology is based on the contactless sensing of mechanical manifestations of individual functions. The patient does not need to have any attached sensors. In terms of vital signals, it is currently possible to obtain heart and respiratory rate.

\section{Methodology}

As both systems LINis and Vitalmonitor are focused on continuous monitoring of the patient in the bed, we investigated the issues that have direct impact on the quality of patient care.

Patients must be assured of not only primary care but also a safe environment in terms of future illness or other injury (Piligrimiene, 2008). Sudden falls means a great danger for patients. Falls are serious problems from the human, medical and financial point of view. As the average age of the patient who falls is over 65 years, the risk of injury is high. Additional information systems in conjunction with modern beds have the potential to improve healthcare services.

Our goal was to prove this fact and to demonstrate an identification of measurable effects to enable cost reduction. We first identified the key problems associated with patients' falls (see the subchapter "Identification of key indicator for measuring"). For this purpose, we used all available studies of patients' falls in the Czech Republic, one study from Switzerland and one from the United Kingdom to include other countries from Europe.

Subsequently we analysed the process relating to the control of the patients in beds (see the subchapter "The process of the patient's control") and we realized the measurement of this process in two medical facilities in the Czech Republic. The first one was a county medical facility of medium size and the other was a large-sized public health facility. We investigated potential time savings because patient's control could be partially replaced by non-standard healthcare systems.

According to McGlynn (McGlynn, 2008), efficiency of care is a cost measure of care associated with a specified level of quality. The relationship between cost and level of quality could be assessed differently. In the end we analysed the distribution of benefits of non-standard healthcare systems for different categories of medical facilities (see the subchapter "Evaluation of benefits following from supplementary software").

\section{Identification of key indicator for measuring}

The first analysis was performed on the basis of five independent studies of patients' falls: three from the Czech Republic (LINET 2010, 2011; Juraskova, 2007), one from the United Kingdom (Healey et al., 2008) and one from Switzerland (Schwendimann, 2006). The data sample is described in Table 1. The reason for the use of these studies is the inability to achieve the required sample size.

Table 1

Range of surveys

\begin{tabular}{|c|c|c|c|l|}
\hline $\begin{array}{c}\text { Period of } \\
\text { data } \\
\text { collection }\end{array}$ & $\begin{array}{c}\text { Number } \\
\text { of } \\
\text { hospitals }\end{array}$ & $\begin{array}{c}\text { Number } \\
\text { of patients } \\
\text { monitored }\end{array}$ & $\begin{array}{c}\text { Number } \\
\text { of falls }\end{array}$ & $\begin{array}{l}\text { Country of } \\
\text { survey }\end{array}$ \\
\hline $1999-2003$ & 1 & 34972 & 3842 & Switzerland \\
\hline $2002-2003$ & 15 & 335945 & 3913 & $\begin{array}{l}\text { Czech } \\
\text { Republic }\end{array}$ \\
\hline $2005-2006$ & 472 & NA & 206350 & $\begin{array}{l}\text { United } \\
\text { Kingdom }\end{array}$ \\
\hline $2006-2007$ & 1 & 1190 & 225 & $\begin{array}{l}\text { Czech } \\
\text { Republic }\end{array}$ \\
\hline 2011 & 23 & 571221 & 5735 & $\begin{array}{l}\text { Czech } \\
\text { Republic }\end{array}$ \\
\hline
\end{tabular}

Although the original purpose of these studies was different, the number of monitored parameters was sufficiently large to provide enough data for analysis from our point of view. Selected data related primarily to patient falls and their causes.

These surveys found that almost half of all falls dealt with falls from bed $(20 \%)$ and with falls when patients 
were standing up (27\%). (Juraskova, 2007) These types of falls can be identified by using the LINis and Vitalmonitor systems.

The purpose of our first analysis was to identify key indicators for measuring the benefits of non-standard information systems. The important prerequisite was that special beds with contactless monitoring of patients were not installed in any of the hospitals investigated. We analyzed the following indicators: 1) time of falls, 2) presence of a nurse at falls, 3) falls notification, and 4) injury from falls, their type and time from the fall to its discovery. The following paragraphs indicate the main findings and related problems.

\section{1) Time of falls}

Findings. The analysis showed that almost $80 \%$ of all falls happened in the night between 10:00 p.m. and 5:59 a.m. The percentage of falls that happened during the day (6:00 a.m. to 9:59 p.m.) was significantly lower - 10-20\%.

Problems. Night falls represent the greatest risk. If the hospital does not have equipment for notification of the fall, it can take a very long time until a nurse finds it which can cause many complications. During the day, the risk of not detecting early fall is considerably reduced because medical staff is actively moving or an accident is notified by other patients.

\section{2) Presence of a nurse at falls}

Findings. Nearly $85 \%$ of the falls happen without the presence of medical staff which could provide assistance (Juraskova, 2007). Nurses are present at $11 \%$ of the falls, the other $4 \%$ of persons who are present at the falls are hospital attendants, doctors or physiotherapists.

Problems. Patients are in most cases dependent on other people to report the accident. Patients are usually not able to stand up alone, due to their age, and often also not able to call for help.

\section{3) Falls notification}

Findings. Approximately $43 \%$ of the medical staff hear the fall, $32 \%$ of falls are reported by other patients in the same room by bell or in $9 \%$ of cases by voice. The patient is able himself to call for help in $7 \%$ and by bell in $2 \%$ of cases. (LINET, 2010)

Problems. We discussed the problems of falls notification with staff in a few hospitals. The most dangerous situations are cases in which the patient must notify the fall alone. Even in cases when staff hears the fall, it takes some time to identify the room in which the fall occurred.

\section{4) Injury from falls}

Findings. According to the study of Juraskova (2007) $48.5 \%$ of all falls lead to some kind of injury. Healey, et al (2008) even refers to 26 dead patients.

Problems. Every complication may substantially affect the health of the patient. Late detection may aggravate injuries. Serious injuries or even death of patients cause loss not only for families but also for the health care facility in many ways.

\section{Partial conclusion to the identification of key indicators}

When using additionally installed information systems (IS), medical staff knows at any time, whether the patient is lying in the bed or not. The monitoring of patients' presence in the bed and leaving the bed gives completely new and unique capabilities that were not possible until now. After studying all the analysis we can say that from the perspective of patient safety, these systems are a huge benefit. The differences between the identification of the patient leaving the bed without IS (from minutes to hours) and with IS (in seconds) are enormous. All identified key indicators are measurable (they are suitable for measuring progress) and they are closely linked to the quality of care.

\section{The process of the patient's control}

The bed with the Vitalmonitor system does not have diagnostic equipment. Patients are divided into three groups in hospital:

- patients who require continual supervision; they are in the intensive care unit,

- patients with increased care; they are in standard rooms but under regular supervision according to the plan (for instance every 15 minutes),

- patients with standard care; the supervision is in an interval of hours.

The implementation of the LINis and Vitalmonitor systems concerns the patients with increased and standard care. In both cases the implementation improves patient care because they are under continuous monitoring.

Our second analysis focused on the work of nurses and other medical staff, who are in direct contact with the patient the most often. On the basis of our literature review (Johansson et al., 2012; Winter et al., 2011) and interviewing the staff in hospitals, we created a model of the patient's control process. The situation in developing countries was also taken into consideration (FernandezSola et al., 2011). The nursing process is a key process which contains a number of other sub-processes: patient's admission, patient examination, diagnosis, determining nursing strategy, nursing interventions and releasing the patient. Modern beds with the implemented contactless vital signals monitoring system will affect above all the sub-process of nursing interventions. This sub-process contains the following activities: bandaging, administration of medication, chronic medication, patient's control, sampling of biological material, preparation for investigation, preparation for surgery and nurse's round. This analysis focused on the "patient's control" activity realized for patients with standard care. The patient's control with standard care is the process which is primarily indicated by time-triggered events. Our discussion with medical staff in the Czech Republic uncovered the problem that there is no legislative regulation determining the intensity of the controls. Our survey was performed in two hospitals. The intensity of controls has not been specified by any internal directives or regulations in either of the two hospitals. Nurses are dependent on their own discretion, which is based on their knowledge, experience and the overall current situation. Nurses are trying to have the largest overview of the current situation and thus make frequent checks to prevent problems. One reason is the responsibility for the department during their attendance. Thus, the nurses themselves set the control plan of the patients with standard care. 
The process of the patient's control was analysed in both hospitals and their realization was very similar. The measurement was realized in hospitals, where the Vitalmonitor system was not implemented. After this analysis, we simulated the process in the environment of health care departments with the Vitalmonitor system. Measurement results before and after deploying the Vitalmonitor system are summarized in Table 2.

Table 2

Time spent checking patients per day before and after deploying the Vitalmonitor system

\begin{tabular}{|l|l|l|}
\hline & \multicolumn{1}{|c|}{ Before } & \multicolumn{1}{c|}{ After } \\
\hline Number of beds & \multicolumn{1}{c|}{29} & \multicolumn{1}{c|}{29} \\
\hline $\begin{array}{l}\text { Average time needed to control one } \\
\text { patient }\end{array}$ & $\begin{array}{l}1 \text { minute } \\
10 \text { seconds }\end{array}$ & $\begin{array}{l}1 \text { minute } \\
10 \text { seconds }\end{array}$ \\
\hline $\begin{array}{l}\text { Total time required for examination } \\
\text { of all patients }\end{array}$ & $\begin{array}{l}33 \text { minutes } 50 \\
\text { seconds }\end{array}$ & $\begin{array}{l}33 \text { minutes } 50 \\
\text { seconds }\end{array}$ \\
\hline $\begin{array}{l}\text { Number of controls during the day } \\
(6: 00-21: 59)\end{array}$ & 3 & 2 \\
\hline $\begin{array}{l}\text { Number of controls during the night } \\
(22: 00-5: 59)\end{array}$ & 2 & 1 \\
\hline Number of automatic controls & 0 & hundreds \\
\hline $\begin{array}{l}\text { Total time required for all controls } \\
\text { within 24 hours }\end{array}$ & $\begin{array}{l}169 \text { minutes } \\
10 \text { seconds }\end{array}$ & $\begin{array}{l}101 \text { minutes } \\
30 \text { seconds }\end{array}$ \\
\hline
\end{tabular}

After the analyses and simulations, we recommend reducing the number of controls from 3 to 2 during the day and from 2 to 1 during the night. The necessary condition is the full implementation of the Vitalmonitor system. If the condition should be fulfilled, patients are monitored 24 hours a day. Beds with the Vitalmonitor system and the proposed reduction of controls allowed the total control time to be shortened by $40 \%$ (from 169 minutes 10 seconds to 101 minutes 30 seconds). This reduction of direct controls brings an important benefit while the quality of health care is maintained. The time saved can be effectively used for other activities or in a combination with other changes may lead to a reduction in the number of employees. We proceeded in the same way with the benefit quantification of the LINis system. Time required for inspections of beds decreased from tens of minute to several seconds. The second benefit is the time of technicians who need not to circumvent the beds. The saved time can be utilised as in the previous case.

\section{Evaluation of benefits following from supplementary software}

We analysed the distribution of benefits for different categories of medical facilities. On the basis of our literature review (Coyne et al., 2009; Jones, 2010; Lettieri, et al., 2009; McCullough, 2008), interviewing managers and companies in healthcare facilities, we created a value added model. Firstly, the following groups of medical facilities were determined according to the adoption curve (Hayden, 2009), medical teams and specializations.

- hi-tech medical facilities (innovators and early adopters); facilities demanding the latest technologies, although they may not have highly qualified and experienced doctors and nurses;

- top medical facilities (early adopters and early majority); specialized facilities combining high-end equipment and cutting-edge medical teams;
- standard medical facilities (late majority and laggards); facilities providing comprehensive care and covering many medical disciplines, where the balance between costs and benefits is the most important.

Secondly, the value added of non-standard healthcare systems was placed into the defined classification scheme. High-tech medical facilities see the greatest value added in technological innovation. They also appreciate the possibilities of overtaking other facilities in terms of equipment, the improvement of patient care quality is secondary and the issue of savings is not taken into consideration. For top medical facilities, the most important value added is the increase in the quality of patient care and accidents prevention. Innovation and savings are partly considered for the decision making process. Standard medical facilities appreciate both the increase in the quality of patient care and cost savings the most. Innovative technology is not important for this kind of facility. Different groups of medical facilities perceive the value added of non-standard healthcare systems differently. For this reason, it is very important to use the value added model during the whole life cycle of the information system (Barber et al., 1998; Ciccarese et al., 2005).

\section{Conclusions}

One of the most monitored aspects of investment in new information technologies is their efficiency. Every project needs to specify why it is being proposed and what will be measurably better if the project is successfully implemented. Not all projects need to be about cutting costs. In health care, benefits are often more intangible like the increasing of timeliness and availability of information or improving patient care. OECD study shows (OECD, 2010), that the use of new systems to save costs is possible: "ICTs can contribute to the reduction of operating costs of clinical services through improvement of the way tasks are performed, by saving time with data processing, reduction in multiple handling of documents etc." The aim of this paper was to demonstrate the evaluation of benefits from investments, which are connected with health care quality improvements. Improving the quality of health care was documented by a list of problems which can be removed on the basis of this investment (in our case it was by using beds with a monitoring system.) The frequency of these problems was demonstrated by five independent studies of patients' falls. Benefits were measured by the reduction of the number of patient's direct controls and by the total time of control activities. We recommended evaluating benefits according to various categories of medical facilities.

This paper shows that it is possible to measure benefits by reducing time demands on medical and technical staff and also demonstrates improvements in patient care quality.

\section{Acknowledgments ${ }^{1}$}

${ }^{1}$ This paper was supported by the grant "Advanced Principles and Models for Enterprise ICT Management" under the number P403/10/0092 at the Czech Science Foundation (GAČR). 


\section{References}

Atkinson, A. A., Banker, R. D., Kaplan, R. S., \& Young, M.S. (2000). Management Accounting. New Jersey : Prentice Hall International.

Barber, J. B., Koch, K. E., Parente, D., Mark, J., \& Davis, K. M. (1998). Evolution of an Integrated Health System: A Life Cycle Framework. Journal of Healthcare Management, 43(4), 359-377.

Ciccarese, P., Caffi, E., Quaglini, S., \& Stefanelli, M. (2005). Architectures and Tools for Innovative Health Information Systems: The Guide Project. International Journal of Medical Informatics, 74(7-8), 553-562. http://dx.doi.org/10.1016/j.ijmedinf.2005.02.001

Coyne, J. S., Richards, M. T., Short, R., Shultz, K., \& Singh, S. G. (2009). Hospital Cost and Efficiency: Do Hospital Size and Ownership Type Really Matter?. Journal of Healthcare Management, 54(3), 163-175.

de Lusignan, S., \& Teasdale, S. (2008). Achieving Benefit for Patients in Primary care Informatics: the Report of a International Consensus Workshop at Medinfo 2007. Informatics in Primary Care, 15(4), 255- 261.

Elzinga R., Ben-Tovim D., \& Phillips, P. A. (2003). Charting the Safety and Quality of Health Care in Australia: Steps Towards Systematic Health Care Safety and Quality Measurement and Reporting in Australia. A Report Commissioned by the Australian Council on Safety and Quality in Health Care. Canberra: ACSQHC.

Fernandez-Sola, C., Granero-Molina, J., Aguilera-Manrique, G., Peredo-de Gonzales, M. H., Castro-Sanchez, A. M., \& Perez Galdeano, A. (2011). Strategies to Develop the Nursing Process and Nursing Care Plans in the Health System in Bolivia. International Nursing Review, 58(3), 392-399. http://dx.doi.org/10.1111/j.1466-7657.2011.00884.x

Feuerlicht, G. (2010) Simple Metric for Assessing Quality of Service Design. San Francisco 07.12.2010 - 10.12.2010. In: Service-Oriented Computing - ICSOC 2010 Workshops. New York : Springer, 2011, 133-143.

Hayden, J. (2009). Introduction to Health Behavior Theory. Jones \& Bartlett Learning.

Healey, F., Scobie, S., Oliver, D., Pryce, A., Thomson, R., \& Glampson, B. (2008). Falls in English and Welsh Hospitals: a National Observational Study Based on Retrospective Analysis of 12 Months of Patient Safety Incident Reports. The International Journal of Healthcare Improvement: Qual Saf Health Care, 17(6), 424-430 http://dx.doi.org/10.1136/qshc.2007.024695

Healthcare Informatics Research. (2009). The Economy's Impact on Healthcare IT Spending. Hospital Leaders Retrench for a Continuing Recession.

Ilminen, G. R. (2003). Improving Healthcare Quality Measurement. Quality Progress, 18(12), $62-66$.

Jones, R. P. (2010). Myths of Ideal Hospital Size. Medical Journal of Australia, 193(5), 298-300.

Juraskova, D. (2007). Patient' Hospitalization and His Safety. (in Czech) EuroProfis.

Johansson, K., \& Lindahl, B. (2012). Moving between Rooms - Moving between Life and Death: Nurses' Experiences of Caring for Terminally ill Patients in Hospitals. Journal of Clinical Nursing, 21(13-14), $2034-2043$. http://dx.doi.org/10.1111/j.1365-2702.2011.03952.x

Kaye, R., Kokia, E., Shalev, V., Idar, D. \& Chinitz, D. (2010). Barriers and Success Factors in Health Information Technology: A Practitioner's Perspective. Journal of Management \& Marketing in Healthcare, 3(2), 163-175. http://dx.doi.org/10.1179/175330310X12736577732764

Kunstova, R. (2012). Process Support of Business and IT Management in Czech Companies. Aalborg 16.10.2011 18.10.2011. In: Re-conceptualizing Enterprise Information Systems. London : Springer, 168-181.

Kunstova, R. (2011a). Communications in Computer and Information Science: Assumptions for Business and IT Alignment Achievement. Ostrava 07.07.2011 - 09.07.2011. In: Digital Information Processing and Communications [CD-ROM]. [online] Berlin: Springer Verlag, 320-332. Available from internet: http://www.springer.com/east/home/computer/ai/book/978-3-642-22388-4.

Kunstova, R. (2011b). Changes in Position of the IT Department in Organizations. Jindrichův Hradec 07.09.2011 09.09.2011. In: IDIMT-2011. Linz: Trauner Verlag Universitat, 71-78.

Kunstova, R., \& Potancok, M. (2010). Analysis of the Effects of Digitalization on Radiodiagnostic Workplace (in Czech) Systémová integrace [online], 2010, 17(4), 86-95. Available from internet: http://cssi.cz/cssi/systemova-integrace42010.

Lettieri, E., \& Masella, C. (2009). Priority Setting for Technology Adoption at a Hospital Level: Relevant Issues from the Literature. Health policy, 90(1), 81-88. http://dx.doi.org/10.1016/j.healthpol.2008.07.007

LINET. (2010). Falling Study (in Czech). CVUT. Zelevcice: LINET spol s.r.o.

LINET. (2011). Falling Study (in Czech). Zelevcice: LINET spol. s.r.o.

Maryska, M. (2011a). Approaches to the Management of Economics Efficiency in Business Informatics. IJEEEE 2011 [online], 1(1), 15-21. Available from internet: http://www.ijeeee.org/Papers/003-C00067.pdf. 
Maryska, M. (2011b). Economic Processes in Management of Business Informatics Economic - ICT Invesment Plan. Shanghai 11.03.2011 - 15.03.2011. In: Conference on Computer Research and Development [CD-ROM]. Shanghai: IEEE Press, 1-6.

Maryska, M. (2011c). Economic Processes in Management Business Informatics Economic - Process of ICT Costs Analysis. Shanghai 11.03.2011 - 15.03.2011. In: EBMM 2011 (Economics Business and Marketing Management) [CD-ROM]. Shanghai : IEEE, 184-189.

Maryska, M. (2010). Reference Model for Measuring and Analysing Costs - Particularly in Business Informatics. Journal of Systems Integration [online], 1(1-2), 54-61. Available from internet: http://www.si-journal.org/index.php /JSI/article/viewFile/49/31.

McCullough, J. S. (2008). The Adoption of Hospital Information systems. Health Economics, 17(5), 649-664 http://dx.doi.org/10.1002/hec.1283

McGlynn, E. A. (2008). Identifying, Categorizing, and Evaluating Health Care Efficiency Measures. Final Report (prepared by the Southern California Evidence-based Practice Center-RAND Corporation, under Contract No. 28200-0005-21). AHRQ Publication No. 08-0030. Rockville, MD: Agency for Healthcare Research and Quality.

NCR. (2009). The Economy's Impact on Healthcare IT Spending. A Healthcare Informatics Research Study [online], Available from internet: www.ncr.com/documents/hc_ITstudy_jan09.pdf.

OECD (2010). Improving Health Sector Efficiency: The Role of Information and Communication Technologies. Paris: Organisation for Economic Co-operation and Development.

OECD. (2011). Health at a Glance 2011. OECD Indicators. OECD Publishing. Available from internet: http://dx.doi.org/10.1787/health_glance-2011-en

Piligrimiene, Z., \& Buciuniene, I. (2008) Different Perspectives on Health Care Quality: Is the Consensus Possible? Inzinerine Ekonomika-Engineering Economics(1), 104-110.

Pour, J., \& Vorisek, J. (2011). Results of the survey of IS/ICT Management in the Czech Republic (in Czech). Systemova integrace [online]. 18(1), 15-34. Available from internet: http://www.cssi.cz/cssi/k-vysledkum-pruzkumu-ceskeinformatiky

Schwendimann, R., Geest S., \& Milisen, K. (2006). Characteristics of in-Patient Falls in Different Hospital Department. Patient falls: a Key Issue in Patient Safety in Hospitals. Available from internet: http://edoc.unibas.ch/ 495/1/DissB_7645.pdf

Scobie, S., Thomson, R., McNeil, J. J., \& Phillips, P. A. (2006). Measurement of the Safety and Quality of Helth Care. MJA. 184(10), S51-S55.

Vorisek, J., Jandos, J., \& Feuerlicht, G. (2011). SPSPR Model - Framework for ICT Services Management. Journal of Systems Integration [online], 2(2), 3-10. Available from internet: http://www.si-journal.org/index.php /JSI/article/viewFile/85/58.

Vorisek, J., \& Jandos, J. (2010). ICT Service Architecture - Tool for Better Enterprise Computing Management. Jindrichův Hradec 08.09.2010 - 10.09.2010. In: IDIMT-2010. Linz: Trauner Verlag Universitat, 83-94.

Winter, A., Haux, R., Ammenwerth, E., Brigl, B., Hellrung, N., \& Jahn, F. (2011). Health Information Systems Architectures and Strategies. 2nd Edition. London : Springer-Verlag. http://dx.doi.org/10.1007/978-1-84996-441-8

Renáta Kunstová, Martin Potančok

Nestandartinių sveikatos apsaugos sistemų naudos įvertinimas

Santrauka

Šiais laikais, naudojimasis informacinėmis technologijomis sveikatos ịstaigose, gali ne tik pagerinti pacientu priežiūros kokybę, tačiau taip pat pagreitinti ir pacientų priežiūrą ir tikslumą. Technologijų įtaką galima ịvertinti keliais aspektais: medicininès informacijos kokybės ir pasiekiamumo, diagnostinių sprendimų kokybès bei sveikatos priežiūros paslaugų kokybès. Iš vienos pusès, informacinės technologijos gerina sveikatos priežiūros kokybę, saugumą ir paciento pasitenkinimą, iš kitos pusès, tam reikia nemažų finansinių investicijų. Rengiant investicinius projektus, reikia aiškiai nurodyti jų svarbą, naudą ir kliūtis, su kuriomis galima susidurti. Sveikatos priežiūrai skirtų finansinių infesticijų įvertinimas susiduria su tokiais pačiais iššūkiais, kaip ir finansiniu investiciju organizacijose ivvertinimas: dažnai kaštai būna netiesioginiai ir sunkiai ịvertinami.

Informacinių technologijų diegimas sveikatos ịstaigose, suteikia galimybę gerinti sveikatos priežiūros kokybę, gydymą, pacientų sveikatą. Tokių sistemu pristatymas yra naudingas pasirenkant paciento stebejjimo technologijas. Tokios technologijos yra naudingos ne tik pacientams, bet ir sveikatos priežiūros ịstaigos personalui. Šių technologijų ịdiegimas mažina ir personalo daromas klaidas. Naudojantis tokiomis programomis galima tiesiogiai pateikti informaciją i sveikatos priežiūros informacinę sistemą, kartu paliekant svarbų ir naudingą sveikatos būklès ịrašą informacinėje sistemoje.

Atsižvelgiant $i$ anksčiau pateikta informacija, šio darbo tikslas yra parodyti nauda, gaunama išplètus medicininès informacijos pacientu stebëjimo sistemą. Pacientų stebejjimas (kai jie būna lovoje ar palieka ją), buvo panaudotas norint nustatyti pagrindinius rodiklius, kad būtų ịvertinta nestandartinių informaciniu sistemu nauda. Būtina salyga buvo ta, kad tirtoje ligoninèje būtu lovu, kuriose, pasinaudojant bekontakčiais signalais, būtu galima stebėti ligonio buvimą jose. Pagrindiniai rodikliai yra tokie: 1) kritimo laikas, 2) slaugès buvimas kritimo metu, 3) pranešimas apie kritimą, ir 4) kritimų sukelti sužeidimai, jų tipai ir laikas nuo kritimo iki ligonio atradimo. Naudojant papildomai instaliuotas informacines sistemas (IS), medicinos personalas bet kuriuo metu žino, ar pacientas guli lovoje. Pacientų buvimo lovoje ir lovos palikimo stebejimas, suteikia visiškai nauju ir unikaliu galimybiu, kurios iki šiol nebuvo tirtos. Analizė patvirtino, kad šios sistemos duoda didžiulę naudą, žiūrint ir vertinant paciento saugumo perspektyvas. Skirtumai nustatant lovos palikimo laiką be IS (nuo minučių iki valandu) ir nustatant su IS (per sekundes) yra didžiuliai. 
Išsiaiškinus pagrindinius aspektus nestandartinių informacinių sistemų rodiklių naudos, toliau buvo analizuotas slaugių darbas. Remiantis mokslinės literatūros apžvalga ir ligoninès personalo apklausomis, buvo sukurtas pacientu kontrolės proceso modelis. Paciento kontrolės procesas yra svarbiausias procesas, kuris apima kelis kitus subprocesus: paciento prièmimą, paciento ištyrimą, diagnozavimą, slaugymo strategijos nustatymą, slaugymą ir paciento išrašymą. Šiuolaikinès lovos, su įdiegta bekontakte gyvybinių signalų stebẻjimo sistema, veikia visą slaugymo subprocesą. Ši subprocesą sudaro tokia veikla: tvarstymas, vaistu tvarkymas, lètinių ligu gydymas vaistais, pacientų kontrolè, biologinių medžiagų pavyzdžiu rinkimas, paruošimas tyrimui, operacijai ir medicinos seserų atliekami patikrinimai. Paciento kontrolès procesas buvo vertinamas ligoninèje, kurioje nebuvo ịdiegta Vitalmonitor sistema. Vertinimo rezultatai prieš ir po Vitalmonitor sistemos idiegimo rodo, kad lovos su Vitalmonitor sistema leido sumažinti tiesioginès kontrolès skaičiu $40 \%$, lyginant su visu kontrolès laiku. Tiesioginės kontrolès sumažinimas davè didelę naudą, nes išliko sveikatos priežiūros kokybė.

Straipsnyje taip pat analizuojamas naudos paskirstymas įvairaus lygmens medicinos įstaigoms. Pirmiausia buvo išskirtos šios grupès: modernios, aukšto lygio ir standartinès medicinos įstaigos. Išanalizavus jas nustatyta, kad skirtingos medicinos isstaigu grupès skirtingai pajunta nestandartiniu sveikatos priežiūros sistemu pridètinę vertę. Dèl to labai svarbu naudoti pridètinès vertės modeli per visą informacinès sistemos naudojimo ciklą.

Sveikatos priežiūros istaigose dažnai gaunama nauda yra nemateriali, pvz.: informacijos gavimas laiku arba paciento priežiūros pagerinimas. Šis darbas parodo, jog imanoma ịvertinti nauda, sumažinant medicininio ir techninio personalo laiką, taip pat gerinant paciento priežiūros kokybę.

Raktažodžiai: sveikatos apsauga, informacine stebëjimo sistema, ligoninès lovı valdymo informacinè sistema, naudos įvertinimas.

The article has been reviewed.

Received in September, 2012; accepted in April, 2013. 